\title{
PERLINDUNGAN HUKUM TERHADAP HAK-HAK KONSUMEN PENUMPANG PESAWAT UDARA DALAM PEMBELIAN PREMI ASURANSI MELALUI SITUS TRAVELOKA
}

\author{
LEGAL PROTECTION OF CONSUMER RIGHTS IN THE \\ PURCHASE OF THE AIRPLANE'S PASSENGERS INSURANCE \\ PREMIUMS THROUGH TRAVELOKA SITES
}

\author{
Gannis Indra Setyawan \\ Staf PT. Jasa Raharja (Persero) Cabang Nusa Tenggara Barat \\ Email : gannis_indra@yahoo.com \\ Kurniawan \\ Universitas Mataram \\ Email : kurniawan3377@gmail.com \\ Lalu Wira Pria Suhartana \\ Universitas Mataram \\ Email : wip.intan@gmail.com
}

\begin{abstract}
In terms of proof of insurance, closing the Government as the regulator so that the parties make a firm rule about the obligation of the insurance company or the airline delivered a list of passenger aircraft to the Airport Authority, either online or integrated with the tickets so that in the event of an accident, the insured as well as ahliwaris have the certainty of a guarantee given by the insurance company. The result of this research shows that traveloka as a provider of ticket sales and travel insurance, in addition to providing an explanation of how to order tickets and buy the insurance premiums, should also give a complete explanation of the display about the cooperation carried out with PT. Chubb General Insurance Indonesia Traveloka site, so that users understand the position of the Traveloka as an intermediary services provider of travel insurance.
\end{abstract}

Keywords: Legal Protection; Insurance; Traveloka.

\begin{abstract}
Abstrak
Dalam pembuktian penutupan asuransi, Pemerintah selaku regulator perlu membuat aturan yang tegas tentang kewajiban perusahaan Asuransi maupun maskapai dalam menyampaikan daftar penumpang pesawat udara kepada Otoritas Bandara, baik secara online maupun terintegrasi dengan tiket sehingga pada saat terjadi kecelakaan, tertanggung maupun ahli waris memiliki kepastian jaminan yang diberikan oleh Perusahaan Asuransi. Hasil penelitian ini menunjukkan bahwa Traveloka sebagai penyedia jasa penjualan tiket dan asuransi perjalanan, disamping memberikan penjelasan tata cara memesan tiket serta membeli premi asuransi, sebaiknya juga memberikan tampilan penjelasan yang lengkap mengenai kerjasama yang dilakukan dengan PT. Chubb General Insurance Indonesia, sehingga pengguna situs Traveloka memahami posisi Traveloka sebagai perantara penyedia jasa asuransi perjalanan.
\end{abstract}

Kata Kunci : Perlindungan Hukum; Asuransi; Traveloka. 


\section{PENDAHULUAN}

Salah satu sarana transportasi yang semakin berkembang dewasa ini adalah sarana transportasi udara. Transportasi melalui udara menjadi salah satu pilihan, karena efisiensi waktu yang diperoleh oleh pengguna. Sarana transportasi udara yang canggih tidak dapat menjamin bahwa perjalanan yang dilakukan aman, sehingga tidak menutup kemungkinan akan terjadinya hal-hal yang tidak diinginkan selama perjalanan, misalnya kerusakan pesawat udara maupun kecelakaan pesawat udara. Disamping itu, selama dalam perjalanan situasi dan kondisi alam juga sangat mempengaruhi kelancaran pengangkutan udara yang tentu saja hal tersebut diluar jangkauan manusia untuk mengantisipasinya.

Salah satu cara untuk mengatasi hal tersebut adalah dengan cara mengalihkan risiko (transfer of risk) kepada perusahaan asuransi dengan mengadakan perjanjian asuransi. Asuransi berperan memberikan suatu jaminan terhadap segala kemungkinan terjadinya suatu kerugian di luar kemampuan manusia sendiri, karena kemungkinan kerugian tersebut disebabkan oleh hal-hal di luar kemampuannya serta tidak bisa ditanggulangi sendiri. ${ }^{1}$

Pemesanan tiket pesawat bisa dilakukan melalui Customer Service bandara, secara online maupun Travel Agent. Perkembangan teknologi membawa dampak yang positif. Hak yang diterima penumpang sama antara penumpang yang memesan tiket secara langsung atau melalui online, dengan pemesanan tiket melalui online terdapat beberapa tawaran asuransi tambahan selama perjalanan, sehingga perjalanan menjadi lebih nyaman. Salah satu situs internet yang digunakan oleh masyarakat dalam pemesanan tiket adalah Traveloka, bahkan Traveloka tersedia dalam bentuk aplikasi telefon genggam yang dapat diunduh oleh masyarakat sehingga memudahkan proses transaksi yang mereka lakukan. ${ }^{2}$

Traveloka menawarkan jasa pertanggungan yang disediakan oleh PT. Chubb General Insurance Indonesia (sebelumnya dikenal dengan nama PT. ACE Jaya Proteksi) yang akan menanggung risiko-risiko selama dalam perjalanan dengan pesawat udara.

Asuransi sebagai suatu perjanjian harus mengedepankan Prinsip itikad baik sebagaimana yang diatur dalam Pasal 1338 ayat (3) KUH Perdata yang menyatakan bahwa setiap perjanjian harus dilaksanakan dengan itikad baik oleh para pihak yang mengadakan perjanjian. Penanggung sebagai pihak yang menerima pengalihan risiko dari tertanggung dengan mendapat premi memiliki kewajiban untuk memberikan suatu penggantian atau manfaat kepada tertanggung apabila yang diperjanjikan terjadi, sebagaimana yang di atur dalam Pasal 1 Ayat (1) Undang-Undang Nomor 40 Tahun 2014 tentang Perasuransian. Konsumen dalam artian penelitian ini adalah pengguna jasa pembelian premi asuransi atau pengguna situs Traveloka yang menggunakan jasa aplikasi tersebut dalam pembelian tiket pesawat terbang.

Dari uraian yang dipaparkan, maka permasalahan yang dapat dikemukakan penulis adalah Bagaimanakah hak konsumen penumpang pesawat udara atas asuransi tambahan melalui Situs Traveloka dan Bagaimanakah hubungan hukum antara perusahaan asuransi yang digunakan oleh Situs Traveloka, Traveloka, dan pihak konsumen dari penumpang pesawat udara.

Penelitian ini merupakan penelitian yuridis normative dan menggunakan pendekatan Perundang-Undangan (statute approach) dan Pendekatan Konseptual

\footnotetext{
${ }^{1}$ Man Suparaman Sastrawidjaja, 2003, .Aspek-Aspek Hukum Asuransi Dan Surat Berharga. Bandung : Pt. Alumni, Hlm. 9

${ }^{2}$ https://www.traveloka.com/en-id/about-us Diakses pada tanggal 13 Januari 2019
} 
(conceptual approach). Cara atau teknis pengumpulan bahan hukum yang digunakan adalah studi dokumentasi yakni dengan mencatat informasi dari bahan hukum yang berkaitan dengan Perlindungan Hukum Terhadap Hak Konsumen Penumpang Pesawat Udara Dalam Pembelian Premi Asuransi Perjalanan Melalui Situs Traveloka (Perspektif Undang-Undang Nomor 40 Tahun 2014 Tentang Perasuransian), baik secara normatif maupun berupa ide atau gagasan.

\section{PEMBAHASAN}

\section{Prinsip-Prinsip Dasar Hukum Asuransi}

Secara harafiah, asuransi dalam Kamus Besar Bahasa Indonesia berarti pertanggungan (perjanjian antara dua pihak, pihak yang satu berkewajiban membayar iuran dan pihak yang lain berkewajiban memberikan jaminan sepenuhnya kepada pembayar iuran, apabila terjadi sesuatu yang menimpa dirinya atau barang miliknya yang diasuransikan sesuai dengan perjanjian yang dibuatnya). ${ }^{3}$ Dalam pengertian ini, asuransi disamakan dengan pertanggungan.

Pertanggungan juga diatur dalam Pasal 1774 KUH Perdata, yaitu perjanjian kemungkinan adalah suatu perbuatan yang hasilnya mengenai untung-untungan, baik bagi kedua belah pihak maupun bagi sepihak bergantung pada suatu kejadian yang belum tentu. Perjanjian untung-untungan oleh Wirjono Projodikoro diartikan sebagai persetujuan yang pelaksanaan kewajibannya tergantung dari peristiwa yang belum akan terjadi. ${ }^{4}$ Pertanggungan telah diatur sejak lama dalam Kitab Undang-Undang Hukum Dagang (KUHD) yaitu dalam Pasal 246 yang berbunyi:

"Asuransi atau pertanggungan adalah suatu perjanjian dengan mana seorang penanggung mengikatkan diri kepada seorang tertanggung dengan menerima suatu premi, untuk memberikan suatu penggantian kepadanya karena suatu kerugian, kerusakan, atau kehilangan suatu kemungkinan yang diharapkan, yang mungkin akan diderita karena suatu peristiwa yang tak tertentu."

Lebih lanjut Undang-Undang Nomor 40 Tahun 2014 tentang Perasuransian menjelaskan tentang asuransi yaitu sebagai berikut:

Asuransi adalah perjanjian antara dua pihak, yaitu perusahaan asuransi dan pemegang polis, yang menjadi dasar bagi penerimaan premi oleh perusahaan asuransi sebagai imbalan untuk:

a) memberikan penggantian kepada tertanggung atau pemegang polis karena kerugian, kerusakan, biaya yang timbul, kehilangan keuntungan, atau tanggung jawab hukum kepada pihak ketiga yang mungkin diderita tertanggung atau pemegang polis karena terjadinya suatu peristiwa yang tidak pasti; atau

b) memberikan pembayaran yang didasarkan pada meninggalnya tertanggung atau pembayaranyangdidasarkanpadahidupnyatertanggungdenganmanfaatyangbesarnya telah ditetapkan dan/atau didasarkan pada hasil pengelolaan dana.

Asuransi memiliki beberapa prinsip yang dapat dijadikan dasar bagi para pihak dalam hubungan perasuransian, yaitu:

1) Prinsip kepentingan yang diasuransikan (insurable interest);

Prinsip ini diatur dalam Pasal 250 KUHD yakni:

"Apabila seorang yang telah mengadakan pertanggungan untuk diri sendiri, atau apa-

\footnotetext{
${ }^{3}$ Kamus Besar Bahasa Indonesia Cet. 3, (Jakarta: Balai Pustaka, 1990).

${ }^{4}$ Dr. Santoso Poedjosoebroto,S.H., Beberapa Aspek Tentang Hukum Pertanggungan Djiwa Di Indonesia, Jakarta, Bhratara, 1969, Hal. 76.
} 
bila seorang, yang untuknya telah diadakan suatu pertanggungan, pada saat diadakannya pertanggungan itu tidak mempunyai kepentingan terhadap barang yang dipertanggungkan itu, maka penanggung tidaklah diwajibkan memberikan ganti rugi."

Konsekuensi saat terjadinya pelanggaran terhadap prinsip kepentingan yang diasuransikan ini adalah batalnya perjanjian asuransi. Hal ini terlihat dari bebasnya penanggung dari kewajiban memberikan ganti rugi. Kepentingan yang diasuransikan harus dapat dibuktikan pada saat terjadi kerugian.

2) Prinsip Itikad Baik;

Setiap pihak baik tertanggung maupun penanggung harus memiliki rasa saling percaya pada penutupan asuransi sebagai bentuk itikad baik masing-masing pihak. Mengingat asuransi adalah salah satu bentuk perjanjian, Pasal 1338 ayat (3) KUH Perdata mengatur bahwa setiap pihak harus mempunyai itikad baik.

3) Prinsip Indemnitas;

Pemberian ganti rugi harus seimbang dengan kerugian riil dari tertanggung. Hal ini dapat terlihat dalam Pasal 277 KUHD yang berkaitan dengan asuransi berganda. Pasal 277 KUHD menentukan bahwa apabila suatu objek asuransi yangtelah diasuransikan denganitikadbaiktelahdiberikanpenggantianseluruhnya(penuh)makapertanggungan lainnya (bila ada) akan dibebaskan. Prinsip keseimbangan ini mencegah terjadi penerimaan ganti kerugian yang berlebihan dari penanggung atau para penanggung kepada tertanggung.

4) Prinsip Subrogasi (Subrogation Principle);

Dalamprinsipsubrogasi,tertanggungyangmengalamikerugiantidakdapatmeminta ganti rugi kepada pihak ketiga jika tertanggung telah mendapat ganti kerugian dari penanggung. Sebaliknya, penanggung memiliki hak untuk meminta ganti kerugian kepada pihak ketiga tersebut.

Prinsip subrogasi tercermin dalam Pasal 284 KUHD bahwa seorang penanggung yang telah membayar kerugian sesuatu barang yang diasuransikan, menggantikan pihak tertanggung dalam segala hak yang diperolehnya terhadap orang-orang ketiga berhubung dengan penerbitan kerugian tersebut.

5) Prinsip Kontribusi;

Prinsip kontribusi ini terlihat pada asuransi berganda dimana Pasal 278KUHD mengatur sebagai berikut:

"Bila satu polis saja meskipun pada hari yang berlainan oleh berbagai penanggung dipertanggungkan lebih dari nilainya, mereka bersama-sama, menurut perimbangan jumlah yang mereka tandatangani, hanya memikul nilai sebenarnya yang dipertanggungkan."

Menurut ketentuan ini, apabila terdapat dua atau lebih penanggung makapenggantian dilaksanakan berdasarkan bagian/perbandingan penanggungan sesuai perjanjian yang telah dibuat. Hal ini untuk mencegah tertanggung menerima penggantian kerugian melebihi kerugian tersebut.

\section{Payung Hukum Asuransi Penerbangan dalam Peraturan Perundang-undangan di Indonesia}

Pengertian maupun pengaturan pelaksanaan asuransi penerbangan tidak diatur dalam KUHD, namun setidaknya Undang-Undang Nomor 1 Tahun 2009 tentang Penerbangan mencoba memunculkan aturan tentang asuransi penerbangan. Peraturan 
mngenai perasuaransian dibidang penerbangan dituangkan dalam beberapa peraturan, yakni:

1) Undang-Undang No. 33 Tahun 1964 tentang Dana Pertanggungan Wajib Kecelakaan Penumpang dalam Pasal 3 ayat (1) huruf a dimana dikatakan bahwa tiap penumpang yang sah dari kendaraan bermotor umum, kereta api, pesawat terbang, perusahaan penerbangan nasional dan kapal perusahaan perkapalan/pelayaran nasional, wajib membayar iuran melalui pengusaha/pemilik yang bersangkutan untuk menutup akibat keuangan disebabkan kecelakaan penumpang dalam perjalanan;

2) Peraturan Pemerintah Nomor 17 Tahun 1965 tentang Ketentuan-Ketentuan Pelaksanaan Dana Pertanggungan Wajib Kecelakaan Penumpang. Ketentuan ini mengatur pertanggungjawaban pengangkut yang diimplementasikan dalam bentuk pertanggungan wajib kecelakaan penumpang. Dana pertanggungan wajib tersebut diurus dan dikuasai oleh perusahaan negara yang khusus ditunjuk oleh Menteri. Perusahaan inilah yang akan menjadi penanggung pertanggungan wajib kecelakaan penumpang. Oleh karena itu, Pengangkut mengenakan iuran wajib dalam setiap pembelian tiket berupa Iuran Wajib Jasa Raharja (IWJR).

3) Undang-Undang Republik Indonesia Nomor 1 Tahun 2009 Tentang Penerbangan Pasal 62 ayat 1 mengatur bahwa Setiap orang yang mengoperasikan pesawat udara wajib mengasuransikan:

a) pesawat udara yang dioperasikan;

b) personel pesawat udara yang dioperasikan;

c) tanggung jawab kerugian pihak kedua;

d) tanggung jawab kerugian pihak ketiga; dan

e) kegiatan investigasi insiden dan kecelakaan pesawatudara;

4) Undang-Undang Nomor 1 Tahun 2009 tentang Penerbangan Pasal 179 dan 180 yang berbunyidemikian.a.Pasal179Pengangkutwajibmengasuransikantanggungjawabnya terhadappenumpang dan kargo yang diangkut sebagaimana dimaksud dalam Pasal 141, Pasal 143, Pasal 144, Pasal 145, dan Pasal 146. b. Pasal 180 Besarnya pertanggungan asuransi sebagaimana dimaksud dalam Pasal 179 sekurang-kurangnya harus sama dengan jumlah ganti kerugian yang ditentukan dalam Pasal 165, Pasal 168, dan Pasal 170. Yang dimaksud dengan "iuran wajib asuransi" dalam ketentuan ini adalah asuransi pertanggungan kecelakaan penumpang yang dikenakan sesuai dengan peraturan perundang-undangan di bidang dana pertanggungan wajib kecelakaan penumpang. Ketentuan ini menjadi dasar Pengangkut untuk mengenakan iuran wajib dalam setiap pembelian tiket berupa Iuran Wajib Jasa Raharja (IWJR);

Peraturan Menteri Perhubungan Nomor 77 tahun 2011 tentang Tanggung Jawab Pengangkutan Udara dimana dikatakan bahwa tanggung jawab pengangkut wajib diasuransikan.

\section{Asuransi Perjalanan oleh PT Chubb General Insurance Indonesia}

Selain Asuransi Wajib yang dilaksanakan oleh Jasa Raharja, serta Ketentuan dalam Peraturan Menteri Perhubungan No. 77 Tahun 2011 tentang Tanggung Jawab Pengangkutan Udara yang mengharuskan Maskapai mengasuransikan tanggung jawabnya, Traveloka bersama mitra perusahaan asuransinya yaitu PT. Chubb General Insurance Indonesia mencoba peruntungan melalui bisnis asuransi sukarela, yaitu dengan jenis asuransi perjalanan. Disebut sukarela dan karena sifatnya ditawarkan pada saat pembelian tiket. 
PT. Chubb General Insurance Indonesia memasarkan asuransi umum dan kerugian dengan produknya yaitu personal accident (kecelakaan), asuransi mobil, asuransi rumah, asuransi perjalanan serta travel insurance plus. PT. Chubb General Insurance Indonesia merupakan hasil akuisisi Ace Limited terhadap Chubb Corporation yang berbasis di New York Amerika Serikat. Sebagai perusahaan asuransi dibidang umum, bila dilihat dari laman resmi Otoritas Jasa Keuangan (OJK), PT. Chubb General Insurance Indonesia memang belum tercantum dalam daftar resmi perusahaan asuransi umum. Namun bila mengakses tautan PT. Ace Jaya Proteksi pada daftar perusahaan asuransi umum laman OJK maka akan langsung terarah pada laman PT. Chubb General Insurance Indonesia. ${ }^{5}$

\section{Hak-Hak Konsumen Pesawat Udara Yang Membeli Asuransi Perjalanan Melalui Traveloka dalam hal Keterlambatan dan Pembatalan Jadwal Penerbangan/Per- jalanan}

Pada pokoknya, hak-hak konsumen penumpang pesawat udara diatur didalam Undang-Undang Nomor 1 Tahun 2009 tentang Penerbangan, dan kemudian secara umum diatur dalam Undang-Undang Nomor 8 Tahun 1999 tentang Perlindungan Konsumen. Undang-Undang Nomor 1 Tahun 2009 tentang Penerbangan merupakan pengganti Undang-Undang Nomor 15 Tahun 1992 tentang Penerbangan. UndangUndang Nomor 1 Tahun 2009 telah mengadopsi ketentuan-ketentuan perjanjian internasional dibidang penerbangan.

Hak-hak kosumen pesawat udara diatur didalam Pasal 140-149 tentang Kewajiban Pengangkut. Adapun beberapa pasal yang berkaitan dengan kewajiban-kewajiban pengangkut, yang menjadi dasar pemenuhan hak-hak konsumen didalam pelaksanaan perjanjian Pengangkutan, antara lain :

1. Pasal 141, terdiri atas (3) ayat, yaitu :

(1) Pengangkut bertanggung jawab atas kerugian penumpang yang meninggal dunia, cacat tetap, atau luka-luka yang diakibatkan kejadian angkutan udara di dalam pesawat dan/atau naik turun pesawat udara.

(2) Apabila kerugian sebagaimana dimaksud pada ayat (1) timbul karena tindakan sengajaataukesalahandaripengangkutatauorangyangdipekerjakannya,pengangkut bertanggung jawab atas kerugian yang timbul dan tidak dapat mempergunakan ketentuan dalam undang-undang ini untuk membatasi tanggung jawabnya.

(3)Ahliwarisataukorbansebagaiakibatkejadianangkutanudarasebagaimanadimaksud pada ayat (2) dapat melakukan penuntutan ke pengadilan untuk mendapatkan ganti kerugian tambahan selain ganti kerugian yang telah ditetapkan.

2. Pasal 144 Pengangkut bertanggung jawab atas kerugian yang diderita oleh penumpang karena bagasi tercatat hilang, musnah, atau rusak yang diakibatkan oleh kegiatan angkutan udara selama bagasi tercatat berada dalam pengawasan pengangkut.

3. Pasal 146 mengatur pengangkut bertanggung jawab atas kerugian yang diderita karena keterlambatanpadaangkutanpenumpang,bagasiataukargo,kecualiapabilapengangkut dapat membuktikan bahwa keterlambatan tersebut disebabkan oleh faktor cuaca dan teknis operasional.

4. Pasal 151 menjelaskan maskapai penerbangan wajib memberikan tiket kepada penumpang.

Terkait dengan keterlambatan angkutan udara, Undang-Undang Nomor 1 Tahun 2009 tentang Penerbangan menjelaskan definisi keterlambatan yaitu, terjadinya perbedaan

\footnotetext{
${ }^{5}$ Diakses Melalui Https://Www.Ojk.Go.Id/Id/Default.Aspx Pada Tanggal 13 Januari 2019.
} 
waktu antara waktu keberangkatan atau kedatangan yang dijadwalkan dengan realisasi waktu keberangkatan atau kedatangan. ${ }^{6}$ "

Jenis-jenis keterlambatan kemudian diperjelas dalam Peraturan Menteri Perhubungan Nomor 89 Tahun 2015 Penanganan Keterlambatan Penerbangan (Delay Management) Pada Badan Usaha Angkutan Udara Niaga Berjadwal di Indonesia ("Permenhub Nomor 89 Tahun 2015").

Menurut Pasal 2 Permenhub 89 Tahun 2015, keterlambatan penerbangan pada badan usaha angkutan udara niaga berjadwal terdiri dari:

a. keterlambatan penerbangan (flight delayed);

b. tidak terangkutnyapenumpangdenganalasankapasitas pesawatudara (deniedboarding passenger); dan

c. pembatalan penerbangan (cancelation of flight).

Meskipun demikian, Badan Usaha Angkutan Udara dibebaskan dari tanggung jawab atas ganti kerugian akibat keterlambatan penerbangan karena faktor teknis operasional (faktor yang disebabkan oleh kondisi bandar udara pada saat keberangkatan atau kedatangan), faktor cuaca, dan faktor lain-lain yang disebabkan di luar faktor manajemen airlines, teknis operasional dan cuaca, antara lain kerusuhan dan/atau demonstrasi di wilayah bandar udara.

Sedangkan Konsumen yang membeli Asuransi Perjalanan melalui Traveloka akan mendapatkan perlindungan dari PT Chubb General Insurance Indonesia sebagaimana Pasal 2 Polis Asuransi Perjalanan sebagai berikut :

Apabila, selama Periode Pertanggungan, pada saat Tertanggung melakukan suatu Perjalanan, saat keberangkatan pesawat yang akan digunakan oleh Tertanggung untuk melakukan perjalanan dimaksud mengalami penundaan sekurang-kurangnya selama empat (4) jam berturut-turut pada satu lokasi tunggal tertunda dari jam sebagaimana ternyata dalam rencana perjalanan yang diberitahukan kepada Tertanggung tersebut sebagai akibat dari pemogokan atau aksi industrial, cuaca buruk, bencana alam atau kerusakan mekanik / gagal kerja dari Angkutan Publik tersebut, atau karena pesawat tidak diperkenankan untuk tinggal landas akibat adanya kerusakan mekanis atau struktural, maka Perusahaan akan membayar kepada Tertanggung dimaksud suatu Manfaat yang sesuai sebagaimana diatur dalam Sertifikat Asuransi untuk setiap empat (4) jam penuh keterlambatan (terhitung sejak waktu keberangkatan pesawat sebagaimana dinyatakan dalam rencana perjalanan), sampai pada jumlah Manfaat yang sesuai sebagaimana diatur dalam Sertifikat Asuransi.

\section{Hak- Hak serta Kewajiban lain Penumpang yang di atur dalam Hukum Perlind- ungan Konsumen}

Undang-Undang tentang Perlindungan Konsumen dirumuskan dengan mengacu pada filosofi pembangunan nasional bahwa pembangunan nasional termasuk pembangunan hukum yang memberikan perlindungan tehadap konsumen adalah dalam rangka membangun manusia Indonesia seutuhnya yang berlandaskan falsafah kenegaraan Republik Indonesia, yaitu negara Pancasila dan konstitusi negara Undang-Undang Dasar $1945 .^{7}$

Pada dasarnya hak-hak dan kewajiban-kewajiban penumpang sebagai konsumen didalam Pasal 4 dan 5 Undang-Undang Perlindungan Konsumen. Menurut ketentuan

\footnotetext{
${ }^{6}$ Lihat Pasal 1 Angka 30 Undang-Undang Nomor 1 Tahun 2009 Tentang Penerbangan

${ }^{7}$ Zuhairi, A. (2015). Konstruksi Perlindungan Hukum Bagi Pengadu/Pelapor Kerugian Konsumen Dari Tuntutan Pencemaran Nama Baik Oleh Pelaku Usaha/Produsen. Jurnal IUS Kajian Hukum dan Keadilan, 3(1).
} 
Pasal 5 Undang-undang Perlindungan Konsumen, konsumen memiliki hak sebagai berikut: ${ }^{8}$

1. Hak atas kenyamanan, keamanan, dan keselamatan dalam mengkonsumsi barang dan/ atau jasa;

2. Hak untuk memilih barang dan/ atau jasa, serta mendapatkan barang dan/ atau jasa tersebut sesuai dengan nilaitukar dan kondisi, serta jaminan yang dijanjikan;

3. Hak atas informasi yang benar, jelas, dan jujur mengenai kondisi dan jaminan barang dan/ atau jasa;

4. Hakuntukdidengarpendapatdankeluhannyaatasbarangdan/ataujasayangdigunakan;

5. Hak untuk mendapatkan advokasi, perlindungan, dan upaya penyelesaiansengketa perlindungan konsumen secara patut;

6. Hak untuk mendapat pembinaan dan pendidikan konsumen;

7. Hak untuk diperlakukan atau dilayani secara benar, jujur, serta tidak diskriminatif;

8. Hak untuk mendapatkan kompensasi, ganti rugi dan/ atau penggantian, apabila barang dan/ atau jasa yang diterima tidak sesuai dengan perjanjian atau tidak sebagaimana mestinya;

9. Hak-hak yang diatur dalam ketentuan peraturan perundang-undangan lainnya. Menurut Pasal 7 Undang-Undang Republik Indonesia Nomor 8 Tahun 1999 tentang

Perlindungan Konsumen, Kewajiban pelaku usaha adalah sebagai berikut: ${ }^{9}$

1. Beritikad baik dalam melakukan kegiatan usahanya;

2. Memberikaninformasiyangbenar,jelas,danjujurmengenaikondisidanjaminanbarang dan/atau jasa serta memberi penjelasan penggunaan, perbaikan, dan pemeliharaan;

3. Memperlakukan atau melayani konsumen secara benar dan jujur serta tidak diskriminatif;

4. Menjamin mutu barang dan/atau jasa yang diproduksi dan/atau diperdagangkan berdasarkan ketentuan standar mutu barang dan/atau jasa yang berlaku;

5. Memberi kesempatan kepada konsumen untuk menguji, dan/atau mencoba barang dan/atau jasa tertentu serta memberi jaminan dan/atau garansi atas barang yang dibuat dan/atau yang diperdagangkan;

6. Memberikompensasi,gantirugi,dan/ataupenggantianataskerugianakibatpenggunaan, pemakaian, dan pemanfaatan barang dan/atau jasa yang diperdagangkan;

7. Memberi kompensasi, ganti rugi, dan/atau penggantian apabila barang dan/atau jasa yang diterima atau dimanfaatkan tidak sesuai dengan perjanjian.

Menurut Bob Widhayahartono bahwa empat hak dasar konsumen (the four consumer basic rights) yang meliputi hak-hak sebagai berikut: ${ }^{10}$

a) Hak atau Memperoleh Keamanan (The Right to Secured)

Setiap konsumen berhak mendapatkan perlindungan atas barang/jasa yang dikonsumsi. Misalnya, konsumsi merasa aman jika produk makanan atau minuman yang dikonsumsinya dirasa aman bagi kesehatan.Artinya produk makanan tersebut memenuhi standar kesehatan, gizi, dan sanitasi serta tidak mengandung bahan yang membahayakan bagi jiwa manusia. Di Amerika Serikat, hak ini merupakan hak tertua yang tidak kontorversial karena didukung oleh masyarakat ekonomi.

b) Hak untuk Memperoleh Informasi (The Right to be Informed)

Setiap konsumen berhak mendapatkan informasi yang jelas dan komprehensif tentang suatu produk barang/jasa yang dibeli (dikonsumsi). Akses terhadap informasi

\footnotetext{
${ }^{8}$ Kurniawan, 2016, Hukum Perlindungan Konsumen. Mataram : Pustaka Bangsa, Hlm. 72

${ }^{9}$ Kurniawan, Op.Cit, Hlm. 79

${ }^{10}$ Happy Susanto, 2008, Hak-Hak Konsumen Jika Dirugikan, Jakarta : Visi Media, Hlm. 25
} 
sangat penting karena konsumen bias mengetahui bagaimana kondisi barang/jasa yang akan dikonsumsi. Jika suatu saat ada risiko negatif dari produk/jasa yang telah dikonsumsinya, konsumen telah mengetahui hal tersebut sebelumnya.Artinya, konsumen memiliki hak untuk mengetahui ciri/ atribut negatif dari suatu produk seperti efek samping dari mengonsumsi suatu produk atau adanya peringatan dalam label/ kemasan produk.

c) Hak untuk Memilih (The Right to Choose)

Setiap konsumen berhak memilih produk barang/jasa dengan harga yang wajar. Artinya, konsumen tidak boleh dalam kondisi tertekan atau paksaan untuk memilih suatu produk tersebut yang mungkin bias merugikan hak-haknya. Ia harus dalam kondisi bebas dalam menentukan pilihannya terhadap barang dan/atau jasa yang akan dikonsumsi.

d) Hak untuk Didengarkan (The Right to be Heard)

Konsumen harus mendapatkan haknya bahwa kebutuhan dan klaimnya bisa didengarkan, baikoleh pelaku usaha yangbersangkutan maupunolehlembaga-lembaga perlindungan konsumen yang memperjuangkan hak-hak konsumen.

Pengetahuan tentang hak-hak dan kewajiban-kewajiban produsen dan konsumen sangat berguna bagi konsumen agar selalu berhati-hati dalam melakukan transaksi ekonomi dan hubungan dagang. Dengan cara seperti itu, setidaknya konsumen dapat terlindungi dari kemungkinan-kemungkinan masalah yang bakal menimpanya. Untuk itulah, perhatian terhadap kewajiban sama pentingnya dengan perhatian terhadap hak-haknya sebagai konsumen. ${ }^{11}$

Kewajiban utama penumpang adalah mematuhi seluruh aturan penerbangan. Mematikan telepon genggam adalah kewajiban yang sering dilanggar penumpang pesawat di Indonesia. Pramugari atau awak kabin biasanya menyampaikan permintaan mematikan handpone dan alat elektonik lain sebelum pesawat take off (lepas landas).

Semenjak terbitnya surat edaran Menteri Perhubungan nomor HK.209/ I/16PHB.2014 kepada seluruh penyelenggara bandar udara pada tanggal 31 Desember 2014, yakni tentang Peningkatan Pelayanan Publik di Bandar Udara Seluruh Indonesia, maskapai penerbangan tidak lagi menjual tiket pesawat di bandara. Maka sejak itu, peralihan penjualan tiket pesawat lebih banyak ditemukan via internet, walau juga ada kantor-kantor maskapai penerbangan di lokasi-lokasi tertentu.

Diera digital seperti ini, booking online tiket pesawat bukan suatu hal yang aneh lagi. CaramencaritiketmurahviaInternetpadaumumnya setiapmaskapaipenerbangan telah memberikan kolom khusus, bahkan page khusus untuk ticketing di website resmi mereka, kemudian membuka masing-masing website maskapai penerbangan tersebut, sepertitraveloka. Padaaplikasi-aplikasitersebut,kitaakandapatmenemukanhargatiket dari setiap maskapai penerbangan yang dicari berdasarkan tanggal keberangkatan dan rute perjalanan. Traveloka juga menyiapkan asuransi bagi konsumen yang memesan tiket penerbangan pulang pergi alias round-trip. Konsumen yang memesan tiket pesawat round-trip dan ingin membeli asuransi, syarat utamanya adalah jarak antara tanggal keberangkatan dan kepulangan tidak boleh melebihi 30 hari. ${ }^{12}$

Sebagai pemakai barang/jasa, konsumen memiliki sejumlah hak dan kewajiban. Pengetahuan tentang hak-hak konsumen sangat penting agar dapat bertindak sebagai konsumen yang kritis dan mandiri. Tujuannya adalah apabila ada tindakan yang tidak adil terhadap dirinya, ia secara spontan menyadari akan hal tersebut. Konsumen

\footnotetext{
${ }^{11}$ Kurniawan,Op.Cit

${ }^{12}$ Traveloka, Https://Www.Traveloka.Com/En/?Id Diakses Pada Tanggal 18 April 2019.
} 
kemudian bisa bertindak lebih jauh untuk memperjuangkan hak-haknya. Dengan kata lain, konsumen tidak hanya tinggal diam ketika menyadari bahwa hak-haknya telah dilanggar pelaku usaha.

Begitu juga dengan penumpang pesawat udara berhak mendapatkan perlindungan atas keamanan dan keselamatan konsumen dalam penggunaan jasa maskapai penerbangan sehingga konsumen terhindar dari kerugian (fisik maupun psikis). Hak konsumen dimana hal tersebut berkaitan dengan perlindungan konsumen dan perlindungan hukum.

Suatusistem perlindungan hukumbagikonsumenjasa angkutanudara adalah suatu sistem yang terdiri dari peraturan perundang-undangan dan prosedur yang mengatur semua aspek yang baik langsung maupun tidak langsung mengenai kepentingan dari konsumenjasa angkutan udara. Darisistem perlindungan hukum tersebut dapatdilihat unsur-unsur perlindungan konsumen, yaitu ${ }^{13}$ :

1. Keselamatan penerbangan

2. Keamanan penerbangan

3. Kenyamanan penerbangan

4. Pelayanan penerbangan

5. Pertarifan

6. Perjanjian angkutan udara

\section{Hubungan Hukum Antara Perusahaan Asuransi, Traveloka dengan Penumpang} Pesawat Udara Yang Membeli Premi Asuransi Perjalanan di Traveloka

Dalam hukum asuransi, ditetapkan bahwa objek pertanggungan dalam asuransi, bisa berupa benda dan jasa, kesehatan, tanggung jawab hukum, serta berbagai kepentingan lainnya yang dimungkinkan bisa hilang, rusak ataupun berkurang nilainya. Dalam penutupan asuransi perjalanan melalui traveloka, timbul hubungan hukum antara Perusahaan Asuransi pada situs Traveloka, Pihak Traveloka selaku penyedia situs, serta penumpang pesawat udara yang membeli premi pada situs Traveloka. PT Chubb General Insurance Indonesia yaitu Perusahaan Asuransi perjalanan pada situs Traveloka adalah sebagai Penanggung. Traveloka adalah Pihak Ketiga yaitu Badan Usaha yang menyalurkan pemasaran Asuransi dari PT Chubb General Insurance Indonesia. Sedangkan Penumpang pesawat udara yang membeli Premi pada Traveloka dalam hal ini adalah pihak Tertanggung.

Tertanggung mengadakan asuransi dengan tujuan mengalihkan risiko yang mengancam harta kekayaan atau jiwanya. Dengan membayar sejumlah premi kepada perusahaan asuransi (penanggung), melalui Pihak ketiga, maka sejak itu pula risiko beralih kepada penanggung.

Dalam prakteknya kerugian/resiko yang timbul dapat bersifat sebagian (partial loss), tidak semuanya berupa kerugian total (total loss). Dengan demikian, tertanggung mengadakan asuransi bertujuan untuk memperoleh pembayaran ganti kerugian yang sungguh-sungguh diderita.

Dalam pembayaran ganti kerugian oleh perusahaan asuransi berlaku prinsip subrogasi (diatur dalam pasal 1400 KUH Perdata) dimana penggantian hak si berpiutang (tertanggung) oleh seorang pihak ketiga (penanggung/pihak asuransi) yang membayar kepada si berpiutang (nilai klaim asuransi) terjadi baik karena persetujuan maupun karena undang-undang.

\footnotetext{
${ }^{13}$ Kurniawan, Op.Cit
} 
Agus Prawoto dalam bukunya berpendapat bahwa, Asuransi mempunyai beberapa sifat dalam pertanggungan, yaitu ${ }^{14}$ :

1. Kontrak asuransi merupakan aleatory contracts, yaitu dalam perjanjian jumlah yang dibayarkan tidak sama besarnya dengan banyaknya jumlah uang yang akan diterima;

2. Dalam pertanggungan tidak ada tawar menawar untukmembuatperjanjianitu (contract of adhesion). Kontrak disusun oleh perusahaan asuransi, di mana kita menerimaatau menolak tersebut (to take it or life it);

3. Perjanjian asuransi merupakan konrak yang unilateral(unilateral contract), artinya perjanjian berlaku secaraunilateral andaikata si tertangung telah membayar premi perusahaan asuransi harus melunasi ganti kerugian atau apayang telah dijanjikan.

4. Meskipun perusahaan asransi telah berjanji untuk membayarganti-rugi, tapi tertanggungharus memenuhisyarat-syarat(kondisi), misalnya sajabilaterjadikerugian dikatakandalam kontrak bahwa dalam satu hari harus memberitahukankepada perusahaan asuransi, kalau tidak melaporkan,mungkin yang terjadi tidak akan diganti.

5. Kontrak asuransi harus dibuat secara jujur dan dikatakanfaith " a contract uberrimac fidei/contract of utmost goodfaith" Hal ini tertama harus diperhatikan pada asuransipengangkutan, karena perusahaan asuransi tidak mempunyaicukup waktu untuk meneliti calon pembeli asuransi lebih banyak.

6. Perjanjian asuransi merupakan contract of indemnity yang artinya kita tidak boleh mencari keuntungan dalam suatukontrak asuransi, umpamanya sengaja merusak barang dengantujuan dapat penggantian yang baru.

Berkaitan dengan uraian diatas, dengan tepat Emmy Pangaribuan Simajuntak mengatakan:"Kemungkinan akan kehilangan, kerusakan harta kekayaan atau property damage, merupakan suatu kejadian yang tidak pasti. Kemungkinan menderita kerugian ini tidak hanya mengenai hartakekayaan melainkan juga mengenai badan dari manusia itu sendiri (bodily injury), misal cacat badan dan peristiwa mati. ${ }^{15}$ Selain salah satu upaya manusia untuk mengalihkan risikonya sendiri, ialah dengan jalan mengadakan perjanjian pelimpahan risiko dengan pihak lain. Perjanjian semacam itu disebutsebagai perjanjian asuransi atau pertanggungan. Pokok pikiran tersebut diatas dikutip banyak sarjana dengan suatu pendapat yang senada sebagai berikut :

"Pertanggungan itu mempunyai tujuan pertama-tama adalah mengalihkan risiko yang ditimbulkanperistiwa-peristiwa yang tidak dapat diharapkan terjadinya itu kepada orang lain yang mengambil risiko untuk menggantikerugian." 6

Tertanggung mengadakan asuransi dengan tujuan mengalihkan risiko yang mengancam harta kekayaan atau jiwanya. Dengan membayar sejumlah premi kepada perusahaan asuransi (penanggung), sejak itu pula risiko beralih kepada penanggung. Apabila suatu ketika sungguh-sungguh terjadi peristiwa yang menimbulkan kerugian (risiko berubah menjadi kerugian), maka kepada tertanggung akan dibayarkan ganti kerugian yang besarnya seimbang dengan jumlah asuransinya.

Dalam prakteknya kerugian yang timbul itu dapat bersifat sebagian (partial loss), tidak semuanya berupa kerugian total (total loss). Dengan demikian, tertanggung mengadakan asuransi bertujuan untuk memperoleh pembayaran ganti kerugian yang sungguh-sungguh diderita.Dalam pembayaran ganti kerugian oleh perusahaan asuransi

\footnotetext{
${ }^{14}$ Agus Prawoto, Hukum Asuransi Dan Kesehatan Perusahaan Asuransi Berdasarkan Risk Base Capital (Rbc) Edisi 2, Yogyakarta : BPFE, 1995

${ }^{15}$ Emmy Pangaribuan Simajuntak, 1979, "Peranan Pertanggungan Dalam Usaha Memberikan Jaminan Sosial" Pidato Pengukuhan Sebagai Guru Besar Pada Fakultas Hukum UGM, Departemen Hukum Dagang Fakultas Hukum UGM Yogyakarta.

${ }^{16}$ Ibid.
} 
berlaku prinsip subrogasi (diatur dalam pasal $1400 \mathrm{KUH}$ Per) dimana penggantian hak si berpiutang (tertanggung) oleh seorang pihak ketiga (penanggung/pihak asuransi) yang membayar kepada si berpiutang (nilai klaim asuransi) - terjadi baik karena persetujuan maupun karena undang-undang. Perjanjian asuransi merupakan bagian dari hukum asuransi itu sendiri.

Seluruh transaksi pembelian asuransi merupakan suatu perjanjian (kontrak), yaitu perjanjian yang mengikat secara hukum dan menimbulkan hak serta kewajiban bagi pihak-pihak yang bersangkutan. Jika salah satu pihak gagal melakukan kewajibannya tanpa alasan hukum, perjanjian (kontrak) dianggap dilanggar. Jika Perjanjian (kontrak) atau jika timbul perselisihan di antara pihak-pihak tentang interprestasi dari perjanjian, permasalahannya dapat diselesaikan di pengadilan.

Dalam hal ini, pengadilan memiliki kemampuan untuk menegakkan (enforce) pertimbangannya dan menyelesaikan perselisihan perjanjian. Perjanjian asuransi dimana tertanggung dan penanggung mengikat suatu perjanjian tentang hak dan kewajiban masing-masing, perusahaan asuransi membebankan sejumlah premi yang harus dibayar tertanggung. Premi yang dibayar sebelumnya sudah ditaksirkan dulu atau diperhitungkan dengan nilai risiko yang akan dihadapi. Semakin besar risiko, semakin besar premi yang harus dibayar dan sebaliknya. Perjanjian asuransi tertuang dalam polis asuransi, dimana disebutkan syarat-syarat, hak-hak, kewajiban masing-masing pihak, jumlah uang yang dipertanggungkan dan jangka waktu asuransi. Jika dalam masa pertanggungkan terjadi risiko, pihak asuransi akan membayar sesuai dengan perjanjian yang telah dibuat dan ditandatangani bersama sebelumnya.

Agar dapat memperoleh pertanggungan Asuransi Chubb Travel Insurance berdasarkan Polis ini Tertanggung haruslah bertempat tinggal di Indonesia, berusia sekurang-kurangnya 18 (delapan belas) tahun per tanggal efektif Asuransi dan telah diterbitkan kepadanya Rencana Perjalanan dengan penerbangan yang berangkat dari Indonesia. Apabila Tertanggung telah memperoleh pertanggungan asuransi, maka orang-orang berikut juga dapat diberikan pertanggungan asuransi seperti yang terdapat dalam pasal 2 Polis Asuransi Asuransi Chubb Travel Insurance.

Hak konsumen penumpang pesawat udara atas asuransi tambahan melalui Situs Traveloka adalah menurut Pasal 2 maka dalam polis asuransi perjalanan PT Chubb General Insurance Indonesia, menyatakan bilamana pesawat yang akan digunakan oleh Tertanggung untuk melakukan perjalanan dimaksud mengalami penundaan keberangkatan sekurang-kurangnya selama empat (4) jam berturut-turut pada satu lokasi tunggal sebagaimana tertera pada tiket tersebut sebagai akibat dari pemogokan atau aksi industrial, cuaca buruk, bencana alam atau kerusakan mekanik/gagal kerja dari Angkutan Publik tersebut, atau karena pesawat tidak diperkenankan untuk tinggal landas akibat adanya kerusakan mekanis atau struktural, maka PT Chubb General Insurance Indonesia akan membayar kepada Tertanggung dimaksud suatu Manfaat sesuai ketentuan dalam polis asuransi dimaksud. Apabila terjadi kecelakaan Pesawat Udara, Pada prinsipnya, Penumpang Pesawat Udara akan mendapatkan jaminan pertanggungan kecelakaan dari pihak-pihak yaitu Maskapai Pesawat Udara, PT Jasa Raharja (Persero), Perusahaan Asuransi Perjalanan, dalam hal ini penumpang yang membeli premi asuransi perjalanan di Traveloka (hanya memberikan kompensasi kepada penumpang yang meninggal dunia atau cacat). 


\section{SIMPULAN}

Konsumen pesawat udara yang melakukan transaksi melalui situs atau aplikasi Traveloka mendapatkan pertanggungan pokok yaitu yang dilaksanakan oleh PT. Jasa Raharja (Persero) serta mendapatkan asuransi tambahan selama melakukan transaksi yaitu pembelian premi asuransi dengan PT. Chubb General Insurance, sebuah Perusahaan Asuransi perjalanan pada situs Traveloka.

Hubungan hukum para pihak dalam perjanjian premi asuransi melalui situs traveloka secara umum diatur dalam undang-undang perasuransian dan undangundang penerbangan, serta secara khusus diatur dalam polis asuransi perjalanan oleh PT. Chubb General Insurance Indonesia.

Ketentuan dalam Pasal 2 polis asuransi perjalanan PT Chubb General Insurance Indonesia, menyatakan bilamana pesawat yang akan digunakan oleh Tertanggung untuk melakukan perjalanan dimaksud mengalami penundaan keberangkatan sekurangkurangnya selama empat (4) jam berturut-turut pada satu lokasi tunggal sebagaimana tertera pada tiket tersebut sebagai akibat dari pemogokan atau aksi industrial, cuaca buruk, bencana alam atau kerusakan mekanik/gagal kerja dari Angkutan Publik tersebut, atau karena pesawat tidak diperkenankan untuk tinggal landas akibat adanya kerusakan mekanis atau struktural, maka PT Chubb General Insurance Indonesia akan membayar kepada Tertanggung dimaksud suatu Manfaat sesuai ketentuan dalam polis asuransi dimaksud.

\section{DAFTAR PUSTAKA}

Agus Prawoto, (1995). Hukum Asuransidan Kesehatan Perusahaan Asuransi Berdasarkan Risk Base Capital (RBC) Edisi 2, Yogyakarta : BPFE

Badan Pengembangan dan Pembinaan Bahasa, (1990). Kamus Besar Bahasa Indonesia, cet. 3, Jakarta, Balai Pustaka.

Djoko Prakoso,(2004). Hukum Asuransi Indonesia, Jakarta: PT Rineka Cipta.

Emmy Pangaribuan Simajuntak, (1979). "Peranan Pertanggungan dalam Usaha memberikan Sosial" Pidato Pengukuhan Sebagai Guru Besar pada Fakultas Hukum UGM, Seksi Hkum DagangFakultas Hukum UGM Yogyakarta.

Happy Susanto, (2008). Hak-Hak Konsumen Jika Dirugikan, Jakarta : Visi Media.

Kurniawan, (2016). Hukum Perlindungan Konsumen. Mataram, Pustaka Bangsa.

Man Suparaman Sastrawidjaja, (2003). Aspek-Aspek Hukum Asuransi dan Surat Berharga. Bandung, PT. Alumni.

Santoso Poedjosoebroto, (1969). Beberapa Aspek Tentang Hukum Pertanggungan Djiwa di Indonesia, Jakarta: Bhratara

Soerjono Soekanto, (1996). Sosiologi Suatu Pengantar.Jakarta : Rajawali Press.

Wirjono Projodikoro, (1991). Hukum Asuransi di Indonesia, Jakarta: PT Intermasa

\section{Jurnal}

Asri, A. (2016). Perlindungan Hukum Bagi Konsumen terhadap Produk Pangan yang Tidak Bersertifikat Halal. Jurnal IUS: Kajian Hukum dan Keadilan, 4(2).

Dilaga, R. A. S. (2016). Perlindungan Hukum Terhadap Pencipta Software Game Dalam Perspektif Undang-undang Nomor 28 Tahun 2014 Tentang Hak Cipta. Jurnal 
IUS Kajian Hukum dan Keadilan, 4(2).

Zuhairi, A. (2015). Konstruksi Perlindungan Hukum Bagi Pengadu/Pelapor Kerugian Konsumen Dari Tuntutan Pencemaran Nama Baik Oleh Pelaku Usaha/ Produsen. Jurnal IUS Kajian Hukum dan Keadilan, 3(1).

\section{Website}

Website Resmi Otoritas Jasa Keuangan https://www.ojk.go.id/id/Default.aspx diakses pada tanggal 13 Januari 2019.

Traveloka, https://www.traveloka.com/en/?id Diakses pada tanggal 13 Januari 2019. 